http://dx.doi.org/10.4314/jae.v18i1.1

\title{
Role of the Three Tiers of Government in the Provision of Sustainable Agricultural Extension Service in Nigeria
}

\author{
${ }^{1}$ Issa, F. O. ${ }^{2}$ Aminu, A.B., ${ }^{1}$ Abdullahi, A.Y. and ${ }^{3}$ Abdulazeez, M. A. \\ ${ }^{1}$ Agric Extension and Economics Department, NAERLS/ABU, Zaria \\ Corresponding e-mail: issafola@gmail.com, +2348033339312 \\ ${ }^{2}$ Department of Local Government and Development Studies, ABU, Zaria \\ ${ }^{3}$ Department of Biological Sciences, ABU, Zaria
}

\begin{abstract}
This paper focused on how the three tiers of government actually work in delivering extension services, and whether there is synergy of responsibilities-both financial and managerial-to improve accountability and performance. This analysis provides some informed speculation on what could be expected in terms of outcomes/performance if roles and responsibilities are clearly stated. Thus, it aims to contribute to the process of transformation in the country to reach an agreement on which tier is best suited to undertake extension expenditure responsibilities and how these should be financed. What institutional arrangements would enable better performance in the delivery of extension services? The public extension delivery system operative in Nigeria was reviewed highlighting the major challenges and way forward. The need for a legislated agricultural extension policy championed by the Federal Department of Agricultural Extension (FDAE) was recommended.
\end{abstract}

Key words: Government, sustainable, extension.

\section{Introduction}

There are three tiers of government in Nigeria, namely the federal, state, and local governments. These three levels of government share the authority and responsibility for the provision of agricultural services. The federal government is mainly responsible for regulating and funding agricultural research and development activities. It also provides subsidized inputs (fertilizer) and credit, and shares the responsibility for some agricultural services with the State governments. The State governments share the costs of agricultural subsidies with the federal government, and some of them provide additional fertilizer subsidies. The states are also responsible for providing agricultural extension services. Finally, the local governments are mainly responsible for the actual delivery of various agricultural services. Although the federal government provides subsidized credit, the state and local governments also play important roles in channeling these resources to their constituencies (FMARD, 2001).

Although agricultural extension is on the concurrent list of the constitution, the federal government to-date, has always taken the responsibility for a major portion of the funding, 
policy formulation and direction, while the States' ADPs are the primary agencies responsible for public extension delivery at the grassroots nationwide. The quality of staff and the resources of the LGAs are such that their participation in agricultural extension delivery has only been very minimal, as against the provisions of existing policies. Even with this policy in place, none of the three tiers of government has had the commitment and the will power to implement the tenets of the document with respect to the financing and provision of an effective and efficient agricultural extension service in Nigeria. Worse still, most of the local governments chairmen are neither aware of the document nor its provisions. (Arokoyo, 2009, FMARD, 2012).

The objective of this paper was highlight the role of the three tiers of government in the provision of sustainable agricultural extension service in Nigeria; and to suggest the institutional arrangements that would enable better performance in the delivery of extension services. The public extension delivery system operative in Nigeria was reviewed highlighting the major challenges and way forward.

\section{Historical context}

The current extension performance can be logically linked to the current structure of the fiscal federalism which is a legacy of the military rule. A brief tour through the history of Nigerian federalism reveals sharp turning points in federal and regional fiscal relations, based alternately on principles of derivation, national interest, and the centripetal forces of military governments. With the adoption of a federal constitution in 1954, Nigeria provided fiscal autonomy to its three regions both over expenditure decisions and over a local revenue base (consisting primarily of mining rents, personal income tax, and receipts from licenses). Centrally collected revenues, primarily from export, import and excise duties, was distributed to the regions according to the derivation principle (Khemani, 2001). However, after independence in 1960, the derivation principle was modified in the interest of national unity, and the federal system of government began to be used to accommodate the diverse social and political interests of a multiethnic state.

Since 1966, under successive military regimes, revenue administration and collection became increasingly centralized, and regional allocation was engineered the discretion of the military government. Simultaneously, expenditure responsibilities and government functions also became centralized, with the federal government assuming the role of the engine of social and economic development. Nigeria's federal units grew from three to four regions during 1960-1966, and then to 12 states by 1967. In 1976, local governments became recognized as the third tier of government, entitled to statutory allocations from both federal and state governments, and seven additional states were created bringing the total number to 19. Over the decade of the '90s this number has almost doubled to the current number of 36 states, and 774 local governments, all of which were created under military rule (Khemani, 2001). 
It would appear, therefore, that the current federal arrangement is a direct legacy of military rule, with the attendant risk that states and LGAs were created to behave more as agents of the center, and perhaps for the primary purpose of political distribution of national resources, and not for effective delivery of public services (Khemani, 2001).

\section{Agricultural Extension Delivery Systems Operative in Nigeria}

a. Constitutional provisions for agricultural development

It is pertinent to note that constitutional provision on the development of agriculture and natural resources points to the policy direction agricultural extension service delivery is expected to take. Chapter 2 Section 16, also supported by the Fourth Schedule Section 2 of the 1999 Constitution provided for tripartite and collective efforts by the three tiers of government in the provision of basic infrastructure that encourage rural farmers, processors, marketers, etc to increase productivity and quality of agricultural resources and commodities, thereby increasing both nutritional status and net income and reducing poverty and unemployment. The importance of this was demonstrated by placing agriculture on the concurrent list, with the leading role played by the local governments, followed by state governments, while the federal government is restricted to policy formulation and creation of enabling environment for all actors.

Thus, the current practice of agricultural extension service is not in agreement with the 1999 Constitutional provision. The federal government is now the major player in the implementation of agricultural development, while state governments are the leading players in agricultural extension service delivery. The local governments are practically onlookers with regard to agricultural research, extension and training, providing sporadic interventions in selected areas of vaccinations for animals and provision of farm inputs. This absence of synergy and role sharing in achieving specificity, sustainability and competitiveness in agricultural development is thus the reverse of the constitutional provision (Abubakar, 2011).

\section{b. Government programmes and strategies for agricultural extension}

The existing agricultural extension delivery service is in a state of confusion, as no definite policy is driving the programmes, strategies and practices (Madukwe, 2008, Abubakar, 2011). In the current practice, the federal government is leading in numerous initiatives and programmes, such as the National Food Security Programme (NFSP), Fadama III, Commercial Agricultural Development Programme (CADP), Root and Tuber Extension Programme (RTEP), among others. The implementation of these programmes usually takes its toll of quality personnel from the few state ADP staff, making it near impossible for the ADPs to undertake the basic functions of grassroots extension delivery.

Moreover, State Agricultural Development Programmes (ADPs) are the only formal institutions for delivering agricultural extension services in the country; they are solely managed by various States, that is, with no institutional arrangement with federal or local governments. Visible synergy is only observed on initiatives promoted by the federal government which often reduces both personnel and other resources of these ADPs. This is 
despite the key constraints of the ADPs, such as shortage of extension agents (EAs) (quality \& quantity), inadequate mobility allowances and other key field facilities. To compound the problem, LGAs are not in any way connected with any aspects of grassroots extension delivery as most do not have trained EAs, nor are they involved in promoting agricultural innovations. In most cases, the agriculture departments of LGAs are hardly involved in any real agricultural extension delivery activities.

In terms of finance, there seems to be the absence of visible funding mechanism directed at extension delivery from Federal Government (FG) and LGAs. The State Governments (SGs) provide finances for ADP's operations and counterpart funding of FG initiatives/projects with little impact on grassroots farm families in their states. (Abubakar, 2011).

\section{c. Ambiguous status of local governments}

Reflecting the state of public opinion on this subject, the 1999 Constitution is also somewhat ambiguous with regard to the autonomy of Local Governments from the authority of the state government within whose boundaries they fall. Article 7 empowers the state government to enact legislation with regard to "the establishment, structure, composition, finance and functions" of democratically elected local government councils. Furthermore, even in the Fourth Schedule, which provides a list of functions to be performed by Local Government Councils, some critical areas of basic service delivery that have traditionally been regarded as the responsibility of Local Government Authorities-the development of agriculture inclusive-are now implied to be the responsibility of state governments, with Local Government Council involvement relegated to that of participation in the state's execution of its functions. The Constitution provides that "The functions of a local government council shall include participation of such council in the Government of a State as respects the following matters: (a) the provision and maintenance of primary, adult and vocational education; (b) the development of agriculture and natural resources, other than the exploitation of minerals; ....and (d) such other functions as may be conferred on a local government council by the House of Assembly of the State."

Hence, provision of extension services which is the focus of this paper is assigned as the responsibility of the state and local governments, with no clear legal delineation between the relative roles of these two sub-national tiers of government. As things stand now, the state-level discretion with regard to the powers of the LGAs has led to wide variation in the extent of autonomy afforded to LGAs both within and across states-in many cases they function as mere administrative extensions of state governments.

By the constitution, agricultural development was placed as a share responsibility of the State and Local governments. However, State governments appear to be ultimately responsible for the actual delivery of extension services, and often have to take over the activities and responsibilities of local governments in order to ensure delivery. 


\section{Review of Agricultural Policies in Nigeria}

a. The 2001 Nigerian Agricultural Policy

The 2001 Agricultural policy was perhaps the first to address the issues of public agricultural extension service in Nigeria with particular reference to the roles and responsibilities of the various tiers of government and the private. The new policy thrust was premised on the fact that "self-sufficiency in food production (as propounded by the 1988 Policy) was too limited in scope. Policy objective must transcend self-sufficiency to cover food security" (FMARD, 2002).

The Nigerian Agricultural Policy (NAP) thrust, which was adopted in 2001 and revised thereafter, identified the specific agricultural development-related responsibilities of the different tiers of government. Overall, the federal government is responsible, either directly or indirectly (via fiscal transfers), for funding the provision of certain agricultural services. The state and local governments also have funding responsibilities for some services (e.g., extension). All three levels of government, along with the parastatals and some private companies, participate in the physical production and delivery of agricultural services. The specific responsibilities of the various levels of government are detailed in Table 1. According to NAP, the responsibilities of the federal government include: the provision of a stable and consistent policy environment; and research and development for agricultural technologies. However, the responsibilities for some specific agricultural services have been decentralized to autonomous agencies and public corporations. For example, the agricultural research services have been decentralized to the National Agricultural Research Institutes (NARIs) network. Similarly, the management of irrigation infrastructure has been decentralized through the River Basin Development Authorities (RBDAs) network (FMARD 2001).

Table 1: Allocation of responsibilities for agricultural development across the federal, state and local governments

\begin{tabular}{|l|l|}
\hline \multicolumn{1}{|c|}{$\begin{array}{c}\text { Level of } \\
\text { Government }\end{array}$} & \multicolumn{1}{c|}{ Responsibility } \\
\hline Federal & $\begin{array}{l}\text { (i) Ensure stable macroeconomic and trade policy environments and } \\
\text { the flow of resources for agriculture and the rural economy } \\
\text { (ii) Support rural infrastructure development in collaboration with state } \\
\text { and local governments } \\
\text { (iii) Support research and development for technologies aimed at } \\
\text { agriculture } \\
\text { (iv) Provide support for the input supply, including the provision of } \\
\text { improved seeds and quality control } \\
\text { (v) Support agricultural extension services } \\
\text { (vi) Manage and supervise large dams and irrigation infrastructure } \\
\text { (vii) Control of pests and diseases of national and international } \\
\text { significance } \\
\text { (viii) Promote rural financial institutions and agricultural insurance } \\
\text { (ix) Support agricultural land management and control of land use }\end{array}$ \\
\hline
\end{tabular}




\begin{tabular}{|l|l|}
\hline & (x) Support training and manpower development \\
(xi) Participate in the mapping and development of interstate cattle \\
grazing and watering routes \\
(xii) Promote agricultural commodity marketing institutions \\
(xiii) Maintain fishing terminals and other fisheries infrastructure \\
(xiv) Periodically review agreements on international agricultural trade \\
(xv) Coordinate agricultural data and information management systems \\
\hline State & (i) Provide effective agricultural extension services \\
& (ii) Promote the production of inputs for crops, livestock, fish and \\
forestry \\
(iii) Ensure land access for all those wishing to engage in farming \\
(iv) Develop and manage irrigation facilities and dams \\
(v) Develop pastures and create water access for livestock \\
(vi) Train and develop manpower \\
(vii) Promote the control of plant and animal pests/diseases \\
(viii) Promote rural financial services for smallholder farmers \\
(ix) Invest in rural infrastructure, including rural roads and water \\
supplies, in collaboration with federal and local governments \\
(x) Manage and control forest estates held in trust for local communities \\
\hline (i) Provide effective extension services \\
(ii) Provide rural infrastructure in collaboration with the federal and state \\
governments \\
(iii) Manage irrigation infrastructure \\
(iv) Promote cooperatives and local community institutions \\
(v) Provide land for new entrants into farming, in accordance with the \\
provisions of the Land Use Act \\
(vi) Coordinate data collection at the primary levels
\end{tabular}

Source: FMARD (2001).

NAP's proposals concerning the roles and responsibilities of the various tiers of government have been inconsistent and at times contradictory (Akramov, 2010). The main channel for disseminating knowledge and new agricultural technologies involves the public extension services of FMAWR, ADPs, and local governments. The ADPs, which were launched in the 1970 s by the federal government, were funded with World Bank loans as part of an integrated rural development package (Oladele 2004). Based on a decision of the National Council on Agriculture (NCA), all states agreed to unify their public extension services under ADPs. For the purpose of extension service provision, an ADP divides the State into various cells, each of which is headed by an extension agent. The extension agent reports to a supervisor, who supervises a group of cells and reports to an extension officer of the local government. The extension officer reports to the state director of extension services (Mogues et al. 2008). Within this framework, an extension agent is backed by various subject-matter specialists, and is intended to be the farmers' principal contact for the dissemination of agricultural technology. However, poor linkages between the federal and state agricultural institutions, insufficient numbers of trained staff members, and inadequate logistical support have limited the establishment of efficient unified extension services (ADF 2005). Although the ADPs are state-level institutions, they rely heavily on federal and 
(especially) external funds. Thus, the withdrawal of World Bank funding in 1990s had a significant negative impact on the funding and delivery of extension services in Nigeria (Oladele 2004). This has attendant consequences on the productivity of extension workers. Currently, 55 percent of the total budget revenue is allocated to the federal government, 25 percent to the state governments, and 21 percent to the LGAs (Ekpo 2004). This heavy dependence on federal transfers may lead to poor accountability (Akramov, 2010).

Finally the document stated clearly that federal, state and "local government should jointly adequately finance agricultural extension and rural infrastructure development".

\section{b. The 2008 Agricultural Extension Policy:}

Perhaps, the most recent and most authoritative agricultural extension policy pronouncement by government was enunciated in the 2008 by way of the National Food Security Program document which provided for the establishment of "One-stop" Agricultural Extension Services. Accordingly, "the agricultural extension service will be professionalized by the State governments establishing farm support centres as "One-Stop" facilities in each local government in partnership with the private sector to train and teach new farming techniques" Further, the program will train 10,000 highly competent extension workers per year with the objective of "achieving a ratio of at most of 1:350 Extension Agent/Farm family ratio" (FMAWR, 2008). This pronouncement is a typical government's top-down planning process with no consultation with the States and Local Governments and the private sector. National field surveys make the proposed ratio of 1:350 totally unrealistic in the immediate future in Nigeria considering the current situation on the ground (1 EA to approximately between 2,500-10,000 Farm families depending on the State. A major worry of the policy was that modalities of implementation were neither clearly spelt out nor subjected to wide consultations among the prospective stakeholders (Issa et al., 2010). The policy died a natural death with the termination of the last administration that initiated it.

\section{Agricultural Sector Performance Assessment}

The performance assessment of the sector revealed that although the Nigerian agricultural sector has made some impressive strides in the past decade, these gains will continue to be diluted if some of the following obstacles to the development of the sector are not addressed. According to FGN (2009), there was lack of clarity in the roles of the three tiers of government in agricultural spending and policy-making which results in policy inconsistency, pervading presence of ambiguities of roles within the framework of the governance structure of agricultural management, overlapping and duplication of functions. Consequently, various programs and policies enunciated over the years and supported by Donor/Development partners did not achieve their development objectives or desired impacts due to such policy inconsistencies, lack of coordination and poor policy formulation and implementation (FGN, 2009). 
Furthermore, the 2012 edition of National Agricultural Extension Review and Planning (NAER\&P) meeting on the major problems of extension service delivery noted that the major problem of extension service in the country is due to inadequate funding, very high extension agent (EA): Farm family ratio across the states; existence of parallel extension outfits in most states rendering ADPs inactive; and poor staffing and non-replacement of retired staff.

\section{Major Challenges of Agricultural Extension and Advisory Services in Nigeria}

1. Poor coordination/effort duplication: Systematic collaboration has been lacking among government research, extension and training bodies, and among other public organizations, universities, NGOs, and the private sector. Poor coordination and duplication of efforts limit the system's efficiency and effectiveness. Coordination has been poor, particularly between local governments, ADPs and state ministries of agriculture where the constitutional provisions expect the highest complementary efforts (1999 Constitution). Though, different extension service needs are best fulfilled by different agencies (Swanson et al., 1990); proper coordination will help reduce wasteful duplication of efforts.

2. Poor budgetary provisions: The key constraints of extension services reported by majority of the ADPs was poor funding (NAERLS and NPAFS, 2011). Fund allocation from state governments was found to be grossly inadequate and often disbursed late. Low funding, in addition to other factors, led to the ADPs' inability to meet their required logistic and manpower development needs. It has also resulted in the widespread problem of high EA: farmer ratio and poor staffing. Anambra, Enugu and Rivers states have the highest EA: farmer ratio, with 1:9,407, 1:6,848 and 1:6,749, respectively (NAERLS and NPAFS, 2011).

3. Financial unsustainability: Public sector agricultural extension services are not financially sustainable. State governments have not funded ADPs at sustainable levels. More so, federal and local governments are not visibly involved in ADP funding. Although ADPs have had some positive impact, they have been plagued by shortages of financial resources, especially after the closure of the World Bank loans in the early 1990s for reasons including lack of counterpart funds from the government (World Bank, 2002).

To reduce the financial burden of extension services on government, extension services could be decentralized to the local level and used as a vehicle to reach poor farmers. LGAs were established in Nigeria under a 1976 law to decentralize development programmes to the local level. Under the law, LGAs has a major responsibility to carry out extension. Thus, most LGAs have agricultural units that supply inputs, but their efforts could be channelled to mobilize farmers and engage in extension service provision. However, the capacities of these LGAs will have to be developed to perform this function more effectively (Issa and Issa, 2013).

4. Lack of accountability to farmers: The public sector-led extension delivery system (ADPs), due to its monopolistic tendency and lack of competition, lacks accountability 
especially to the farmers. Nigeria must reform the ADPs and reorganize its extension services to satisfy its farmers' diverse needs and to take note of the fact that farmers are central to the system; and the system was created to serve their needs.

5. Weak REFILS: The research-extension-farmer-input linkage system (REFILS), meant to connect farmers with research and extension systems, has had operational problems. These include shortage of well-maintained vehicles for input distribution and regular contact visits, and lack of quality and adequate personnel. Also, direct financing for the conduct of key activities such as On-Station Research Trial (OSRT), On-Farm Adaptive Research (OFAR), Monthly Technology Review Meeting (MTRM), Small Plot Adoption Techniques/Management Training Plot (SPAT/MTP) is found to be difficult by many ADPs. This underscores the need for the LGAs to take active role in providing extension services in Nigeria.

6. Non-involvement of the key actors and development partners in policy articulation. The establishment of the "One Stop" Extension Service Centres justifies this fact.

\section{Institutional Arrangement Required for better Performance of Agricultural Extension Service in Nigeria}

In order to enhance the performance of agricultural extension in Nigeria; the FMARD through the newly created FDAE should:

1. formulate and review sectoral policies and monitoring the overall performance of the agricultural sector.

2. contribute to the development and promotion of improved agricultural practices.

3. monitor the performance of both public and private sector agricultural sector support services in order to improve their quality and ensure competitive markets.

4. promote the private sector's role in the provision of agricultural services.

There are several serious constraints that the FDAE need to overcome in order to play these new roles effectively including lack of mechanisms for institutional coordination among the various tiers, and between FMARD and the State/LGAs. To overcome this constraint, the Government should strengthen the capacity of FDAE staff by training the staff in policy formulation, analysis, as well as strategic planning and management.

\section{Conclusion}

Agricultural extension is essentially an activity that should be carried out by the lower tiers (State and LGAs) of government. By the positioning of the State and LGAs, they should be more connected to grassroots extension delivery, hire trained EAs, and be more involved in promoting agricultural extension activities. But given the overriding importance of technology dissemination, all the three tiers of government in Nigeria should be involved in jointly financing agricultural extension delivery and monitoring its impact through a 
deliberate plan of action, with clear modalities for contribution (FMARD, 2012). There is need for sustainable funding of agricultural extension activities in Nigeria by the three tiers of government as contained in the action plan of Agricultural Extension Transformation Agenda (AETA). The AETA action plan advocates for clear guidelines and policy which should provide for public financing of extension services to be paid from a consolidated account to fund agricultural extension services, and which the Federal, State and Local governments must contribute.

\section{Policy Recommendations}

Nigeria, after many decades of agricultural extension practice, has no legal framework for her extension activities (Madukwe, 2008; Phillip et al 2009; and Abubakar, 2011). In order to ensure sustained agricultural extension service delivery, agricultural policies must endure and outlive the government that formulated them. The practice of changing macroeconomic policies with successive federal governments is inimical to global best practices. Since Agriculture is on the concurrent list of the constitution, and given its importance, it is imperative that there should be a National Agricultural Extension policy to harmonize the critical elements that are required to power a sustainable and a market-oriented agricultural development through the ADP system and using the commodity value chain approach. The most successful agricultural development stories in both the developed and developing countries have been found in countries that have legislated agricultural extension policies. There are many agencies involved in agricultural extension service in Nigeria each with its own objectives and approach. Some of the approaches fall short of the basic principles and philosophy of extension and may have negative effect on the long run. Therefore, the various tiers of government should act in concert with the new agricultural extension transformation agenda (AETA) to promote an effective role for various stakeholders in the provision of agricultural extension services. The need for an agricultural extension policy is predicated on the fact that such uncoordinated efforts cannot lead to sustainable agricultural extension practice. It is hoped that with the newly created Federal Department of Agricultural Extension (FDAE); this dream will be actualised.

\section{References}

Abubakar, S.Z. (2011). Constraints to effective and sustainable financing of public sector agricultural extension delivery system in Nigeria. The Journal of Agricultural Extension, Vol 16(1), Jupp 1- 13.

African Development Fund (ADF) (2005). Federal Republic of Nigeria: Agriculture and rural institutions support project-appraisal report. Tunis, Tunisia: AFD.

Akramov, K. T. (2009). Decentralization, Agricultural Services and Determinants of Input Use in Nigeria. IFPRI Discussion Paper 00941. 32pp.

Arokoyo, Tunji (2009). "An Effective and Functional Extension Service to Maximize Farmers Productivity" An Invited Paper Presented at the National Conference on Agricultural Finance and the Role of Communication in Sustainable Development in Nigeria, Organized by PR Value Consulting, Murtala Muhamad Library Complex, Kano, Sept. 29th -30th, 2009. 
Ekpo, A. H. (2004). Intergovernmental fiscal relations: The Nigerian experience. Paper presented at the 10th Anniversary of the Financial and Fiscal Commission of South Africa, August 10-12, Capetown International Convention Centre, Capetown, South Africa.

Federal Ministry of Agriculture and Rural Development (FMARD). (2001). The New Nigerian Agricultural Policy Thrust. Abuja, Nigeria: FMARD.

(2002). "Agriculture in Nigeria: Policy (Before and Now) Analysis of the Existing (1988) Agricultural Policy and the Revised Policy" Federal Ministry of Agriculture and Rural development, Abuja.

(2012). Report of the agricultural extension transformation component of the agricultural transformation agenda of the Federal Ministry of Agriculture and Rural Development. Pp 113.

Federal Government of Nigeria (FGN) (2009). Nigeria: Vision 20:2020. The First National Implementation for NV20:2020 (2010 - 2013). Volume 1: The Vision and Development Priorities (The Economic Transformation Blueprint), National Planning Commission, Abuja.

Issa, F. O., Arokoyo, J.O. and Jaji, M.F.O. (2010). The Nigerian agricultural extension practice, administration and sustainability: An overview of the challenges. Proceedings of the $15^{\text {th }}$ Annual Conference of Agricultural Extension Society of Nigeria (AESON) held at Obafemi Awolowo University, lle-Ife, $10^{\text {th }}-14^{\text {th }}$ May. Pp $139-150$.

Issa, F.O. and Issa, M. A. (2013). Building the Capacity of Agricultural Extension Personnel for Effective Implementation of Agricultural Transformation Agenda in Nigeria. Journal of Agricultural Extension. Volume 17 (1), June. Pp 78 - 88. Available online at www.aesonnigeria.org

Khemani, S. (2001). Fiscal Federalism and Service Delivery in Nigeria: The Role of States and Local Governments. Prepared for the Nigerian PER Steering Committee, 24th July. Pp 16

Madukwe, M.C. (2008). Practice without Policy: The Nigerian Agricultural Extension Service. An Inaugural Lecture of the University of Nigeria, Nsukka delivered on April $29^{\text {th }}$. UNN Press, Pp76.

Mogues, T., N. Morris, L. Freinkman, A. Adubi, and S. Ehui. (2008). Agricultural public spending in Nigeria. IFPRI Discussion Paper No. 00789. Washington, D.C.: International Food Policy Research Institute.

National Agricultural Extension and Research Liaison Services (NAERLS) and National Programme on Agriculture and Food Security (NAPFS) (2011). National report of Agricultural performance survey of 2011 wet season in Nigeria. December.175 pp.

Oladele, O. I. (2004). Effect of World Bank loan withdrawal on the performance of agricultural extension in Nigeria. Nordic Journal of African Studies 13 (2): 141-145.

Peterson W, V. Galleno, T. Eponu, A. Wuytts-Fivawo \& M. Wilks (2001). Method for planning effective linkages. Briefing Paper no.45, ISNAR, The Hague, The Netherlands, pp 2-3. 
Phillip, D., Nkonya, E., Pender, J. \& Oni, O.A. (2009). Constraints to Increasing Agricultural Productivity in Nigeria: A Review. Nigeria Strategy Support Program (NSSP), IFPRI Background Paper No.NSSP 006 September, 72pp.

Swanson, B.E., Farmer B.J. and Bahal R. (1990). The current status of agricultural extension worldwide. In: B.E. Swanson (ed.) Report of the Global Consultation on Agricultural Extension. FAO, Rome.

World Bank. (2002). Extension and rural development: Converging views for institutional approaches? Workshop summary. World Bank, Washington DC. 